\title{
THE EFFECTIVENESS OF COOPERATIVE LANGUAGE LEARNING ON TEACHING GRAMMAR
}

\author{
Rina Husnaini Febriyanti \\ Program of English Education, Faculty of Language and Art, University of Indraprasta PGRI \\ Jalan Nangka No. 58C Tanjung Barat, Jagakarsa, South Jakarta 12530 \\ febri_usagi@yahoo.com
}

\begin{abstract}
The aim of this research is to investigate the significant difference in English Grammar achievement scores of the students taught through cooperative learning and those taught by traditional method. The participants were the students of Indraprasta PGRI University who took Grammar subject on the fifth semester that was split into two groups, those are control group (non-cooperative learning) and experiment group (cooperative learning). The number of the participants in the control group (noncooperative learning) is 25 participants and the experiment group (cooperative learning) is 25 participants too. The method used is a quantitative experiment method using True Experimental Design specifically on Posttest-Only Control Design and the data is tested by t-test. The result of data analysis shows the differences on average (Mean) the control group (non-cooperative learning) is 63, 52; analyzed case as amount is 25; Standard Deviation is 19.194 , and average (Mean) the experiment group (cooperative learning) is 79,20; analyzed case as amount is 25; Standard Deviation is 12,111. The T- Test shows that the Sig (2-tailed) is 0,001<0, 05 means Ho is rejected and $\mathrm{Ha}$ is accepted. In conclusion, there is a significant difference in English grammar achievement scores of the students taught through cooperative language learning.
\end{abstract}

Keywords: cooperative language learning, teaching Grammar, English Grammar achievement

\section{ABSTRAK}

Tujuan dari penelitian ini adalah untuk mencari tahu apakah ada perbedaan atau tidak terhadap nilai Grammar dalam bahasa Inggris dengan menggunakan metode Cooperative Language Learning dan dengan metode tradisional. Partisipan adalah mahasiswa semester lima yang mengambil mata kuliah Grammar tahun akademik 2017/2018 yang dibagi menjadi dua kelompok yaitu kelompok kontrol (noncooperative learning) dan kelompok eksperimen (cooperative learning). Jumlah dari partisipan dari kelompok kontrol (non-cooperative learning) adalah 25 mahasiswa dan kelompok eksperimen (cooperative learning) 25 juga. Metode penelitian yang digunakan adalah a quantitative experiment menggunakan True Experimental Design khususnya Posttest-Only Control Design dan data diuji dengan uji T-Test. Data analysis menunjukkan perbedaan rerata average (Mean) kelompok kontrol (noncooperative learning) adalah 63, 52; analyzed case dengan jumlah 25; Standard Deviation adalah 19.194 , dan rerata (Mean) kelompok eksperimen (cooperative learning) is 79,20; analyzed case dengan jumlah 25; Standard Deviation adalah 12,111. Hasil dari T-Test menunjukkan Sig (2-tailed) adalah 0,001 <0, 05 yang artinya Ho ditolak dan Ha diterima. Dapat disimpulkan bahwa ada perbedaan yang signifikan 
dalam nilai Grammar dalam bahasa Inggris dengan menggunakan metode Cooperative Language Learning.

Kata kunci: cooperative language learning, pengajaran Grammar, nilai Grammar bahasa Inggris

\section{INTRODUCTION}

English is an international language, so almost countries in the worldwide put it into their education curriculum. Indonesia is also one of the countries that subsume English in education curriculum. Despite English is a foreign language which is learned in Indonesia, Indonesian learner formally begins study English from primary or junior high school to university level. Otherwise, English is assumed as a difficult subject for EFL learner in Indonesia.

English skills that are taught in Indonesia classified into four skills those are listening, speaking, reading and writing. Out of four skills, there is one component involves in those skills and it is still assumed as the most uneasy component that is called grammar. Grammar is such a complicated thing for Indonesian EFL Learner. Starting from the basic difference one compares to English between Bahasa Indonesia that is tense which doesn't occur in Indonesian verbs up to more complex element in English grammar. Hence, teaching English in Indonesia is a challenging to reach the teaching goal or target.

English teaching method is very important to achieve its target. As Harmer said (2007:24) in the following:

"What seems to be the case, therefore, is that, especially for beginner students, a prestige variety of the language (whether from the inner circle or from anywhere else) will be an appropriate pedagogical model. The actual variety may depend on the wishes on the student, the variety of the teacher herself uses, the learning materials that are on offer, or the school or education authority policy."

In other words, there must be one of many alternative methods that can be chosen to be implemented in teaching and learning process based on each student's need. Related to the previous discussion about mastering grammar for Indonesian EFL learner that is still assumed as a subject that is not an easy to be learned, therefore, it is important to consider close to the most appropriate method one on teaching grammar. Beside of that grammar is the component that involves in four skills in English learning.

Nevertheless, the traditional method nowadays is still used commonly on teaching English in Indonesia. Yet, another method can be applied into teaching English such as cooperative language learning method to investigate of enhancing especially on student's grammar mastery.

The main objective of this study is to investigate the effectiveness of the differences between English grammar classes that are taught with cooperative language learning method and traditional method, or in the question form as follows; Is there any significant difference in English grammar achievement scores of the students taught through cooperative language learning?

Knowing the result of effectiveness of cooperative language learning in teaching grammar may give advantages for not only grammar class but also other classes such as, 
listening, speaking, reading or writing class as those four skills should be mastered for EFL learner. Additionally, CLL method also can be applied in many subjects besides grammar, for instance, linguistic class, English for Specific Purpose class, drama class etc. Therefore, the effectiveness of CLL can be as a method for enhancing not only specific on grammar but also English general mastery.

The definition of grammar is the description of the ways in which English words are combined to form meaningful and acceptable sentences. In technical terms this means: syntax that is the systematic rules by which we group and order words to form phrases, clauses, and sentences and morphology that is the ways in which the forms of words are changed according to their use in phrases, clauses, and sentences (Seely, 2007:2)

Another definition is grammar may be roughly defined as the way a language manipulates and combines words (or bits of words) in order to form longer units of meaning. (Ur, 2006:4) Other definition about grammar is the study of language, specifically, how words are put together. Because of obsessive English teachers and their rules, grammar also means a set of standards that you have to follow in order to speak and write better, however, the definition of better changes according to situation, purpose, and audience (Woods, 2010:9)

On teaching grammar there are several grammar presentation and practice activities should be evaluated according to: how efficient they are, how appropriate they are, the efficiency an activity is gauged by determining: its economyhow time-efficient is it?, its easehow easy is it to set up?, its efficacy- is it consistent with good learning principles? The appropriacy of an activity takes into account: learner's needs and interests, learners' attitudes and expectations (Thornbury, 2002:28)

Patel and Jain (2008:71) says "Methodology is systematic and scientific way of teaching any subject." It means that teaching method is a way to reach the teaching target run successfully. As told by (Scrivener, 2011: 31) in the following:

"A method is a way of teaching. Your choice of method is dependent on your approach, i.e. what you believe about: what language is, how people learn, and how teaching helps people learn. Based on such beliefs, you will then make methodological decision about: the aims of a course, what to teach, teaching techniques, activity types, ways of relating with students, and ways of assessing."

Teaching method can be described of issues identified here at the levels of approach, design, and procedure. In so doing, we will often have to infer from what method developers have written in order to determine precisely what criteria are being used for teaching activities, what claims are being made about learning theory, what type of syllabus is being employed, and so on (Richards and Rodgers, 2001:29) 
Defining from the understanding of teaching methods above it can be concluded that teaching method is an important part or way of the successful key in teaching and learning process.

Cooperative Language Learning is a method that allows all students to work together, each student experiencing the role of teacher and of learner, and each student modeling recognition of and respect for many different skills and learning styles. (Cohen, Brody, and Shevin, 2004:3)

\section{The Seven Keys}

1. Structures

2. Teams

3. Management

4. Class building

5. Team building

6. Social Skills

7. Basic Principles (PIES)

Table 1

According to Kagan (2009:6.24) the purposes and functions of Cooperative language learning is split into two terns those interpersonal and academic. In interpersonal is divided into five classifications they are 1) class building, 2) team building, 3) social skill, 4) communication skill, 5) decision making. And for academic is
Jolliffe (2007:3) said that "Cooperative learning requires pupils to work together in small groups to support each other to improve their own learning and that of others."

Based on Kagan there are seven successful keys in Cooperative language learning (Kagan, 2009:5.2) they are:

\begin{tabular}{|c|c|c|c|}
\hline No & Learning Model & Interpersonal & Academic \\
\hline 1 & Find Someone Who & Class building & $\begin{array}{l}\text { Knowledge } \\
\text { building }\end{array}$ \\
\hline 2 & Think Write Round Robin & Team building & $\begin{array}{l}\text { Procedure } \\
\text { Learning }\end{array}$ \\
\hline 3 & Numbered Heads Together & Social Skills & Processing Info \\
\hline 4 & Match Mine & $\begin{array}{l}\text { Communication } \\
\text { Skills }\end{array}$ & Thinking Skills \\
\hline $\begin{array}{l}5 \\
6\end{array}$ & $\begin{array}{l}\text { Team Stand and Share } \\
\text { Mix-Freeze Group }\end{array}$ & $\begin{array}{l}\text { Social Skills } \\
\text { Class building }\end{array}$ & $\begin{array}{l}\text { Presenting Info } \\
\text { Knowledge } \\
\text { building }\end{array}$ \\
\hline
\end{tabular}


$7 \quad$ Round Table

8 Telephone

9 Timed Pair Share

10 One Stray

Table 2

The explanation of each activity above is in the following numbers:

1. Find Someone Who "Students circulate through the classroom, forming and reforming pairs, trying to "find someone who" knows an answer, then they become "someone who knows." (Kagan, 2009: 6.26)

2. Think Write Round Robin "Students think about their response, then independently write it down before the RoundRobin." (Kagan, 2009: 6.33)

3. Numbered Heads Together "Teammates put their "heads together" to reach consensus on the team's answer. Everyone keeps on their toes because their number may be called to share the team's answer." (Kagan, 2009: 6.30)

4. Match Mine

"Partners on opposite sides of a barrier communicate with precision, attempting to match the other's arrangement of game pieces on a game board." (Kagan, 2009: 6.28)

5. Team Stand and Share "Teams check off or add each idea as it is shared by other teams, sitting down to show every teams' ideas
Team building

Thinking Skills

Social Skills

Procedure

Learning

Communication Processing Info

Skills

Social Skills Presenting Info

have been shared." (Kagan, 2009: 6.37)

6. Mix-Freeze Group

"The classroom is bursting with energy as students rapidly "Mix" around the room, "Freeze" in their tracks, and frantically "Group" to avoid falling into the lost and found." (Kagan, 2009: 6.29)

7. Round Table

"Students take turns generating written responses, solving problems, or making a contribution to a project. In Round Table, students take turns in their teams."'Kagan, 2009: 6.34)

8. Telephone

"One student per team leaves the room during instruction. When students return, teammates provide instruction on the information missed." (Kagan, 2009: 6.37)

9. Timed Pair Share

"In pairs, students share with a partner for a predetermined time while the partner listens. Then partners switch roles" (Kagan, 2009: 6.38)

10. One Stray

"One teammate "strays" from her team to a new team to share or gather information." 
The lists of alternative activities that involves in Cooperative Language Learning above giving many options toward teacher or lectures in teaching an learning process. Moreover, in this study the activity that is applied on research process are "Round Table" and Think Write "Round Robin".

As the research that had been done by Khan and Akhtar in Pakistan (2017:1) entitled "Investigating the Effectiveness of Cooperative Learning Method on Teaching of English Grammar" the study investigated and compared the effect of cooperative learning method and the whole class traditional method in developing English language of the students of 7 th class. The students under control conditions were taught through whole class traditional method and the students in experiment groups were taught through cooperative learning method. The STAD (Student Teams Achievement Divisions) model of cooperative learning was used in this study. The results based on post test scores showed that the STAD model of cooperative learning had significant effect on the achievement of students, both male and female, in learning English grammar at Elementary level. The effect size was also calculated to determine the magnitude of difference between achievements of experimental and control groups which showed high increase in the achievement of treatment groups.

Another research is by Zarifi and Taghavi (2016:1429) within the title is "The Impact of Cooperative Learning on Grammar Learning among Iranian Intermediate EFL Learners" this study was to investigate the effects of cooperative learning activities on Iranian intermediate EFL learners' grammatical competence. This research was a quasi-experimental study and its design was comparison group design. The study included one control and one experimental group. In total, 50 students participated in the study. They were male and female intermediate English language learners studying English in EFL department at Shokuh-e-Danesh Institute, Dehdasht, Iran. Following a workshop on the implementation of cooperative learning activities, the experimental group was exposed to cooperative learning activities. The control group was, on the other hand, provided with traditional grammar learning methods. 25-item grammar tests were given to both groups before and after the eight-week treatment. T-tests were employed to analyze the obtained data. The results of the tests revealed significant differences between the control group and the experimental group regarding their grammar learning through cooperative learning.The findings of the study suggested that cooperative learning had positive effects on Iranian intermediate EFL learners' grammatical competence.

And a research by Trimastuti entitled (2016:269) "The Effectiveness of Cooperative Language Learning in Teaching Vocabulary" the study aims to determine whether the Cooperative Language Teaching and Learning method is more effective than the 
traditional learning to teach vocabulary. This is an experimental quantitative research. The population for this study is freshmen majoring in management. The use of Cooperative Language Teaching and Learning method through engineering teamsgames-tournament (TGT) in the English vocabulary learning is considered to be effective, creative, and fun to increase the students ${ }^{\text {ee }}$ motivation to learn and to improve their vocabulary mastery. The findings showed that the Cooperative Language Teaching and Learning is an effective method to teach vocabulary. It is, thus, recommended that (1) the Cooperative Language Learning and Teaching improve the students' ability to remember vocabulary; (2) students are expected to be more active in the learning process in order to improve the ability to solve the problem of vocabulary (3) the results of this study can be used as an initial step to hold further research.

\section{METHOD}

This research was held in Indraprasta PGRI University that is located on $\mathrm{Jl}$. Nangka No. 58 Tanjung Barat Jagakarsa Jakarta Selatan.

This research uses a quantitative experiment method using True Experimental Design specifically on Posttest-Only Control Design. Based on Sugiyono (2016:112), the kinds of this method is dividing two classes that consist of control and experiment class. For the given treatment class is called experiment class $\left(\mathrm{O}_{1}: \mathrm{O}_{2}\right)$ and it is tested within namely t-test. The design of Posttest-Only Control Design as follows:

\begin{tabular}{|ccc|}
\hline $\mathbf{R}$ & $\mathbf{X}$ & $\mathbf{O}_{2}$ \\
$\mathbf{R}$ & & $\mathbf{O}_{4}$ \\
\hline
\end{tabular}

Figure 1

The research study applies the scheme as follows:

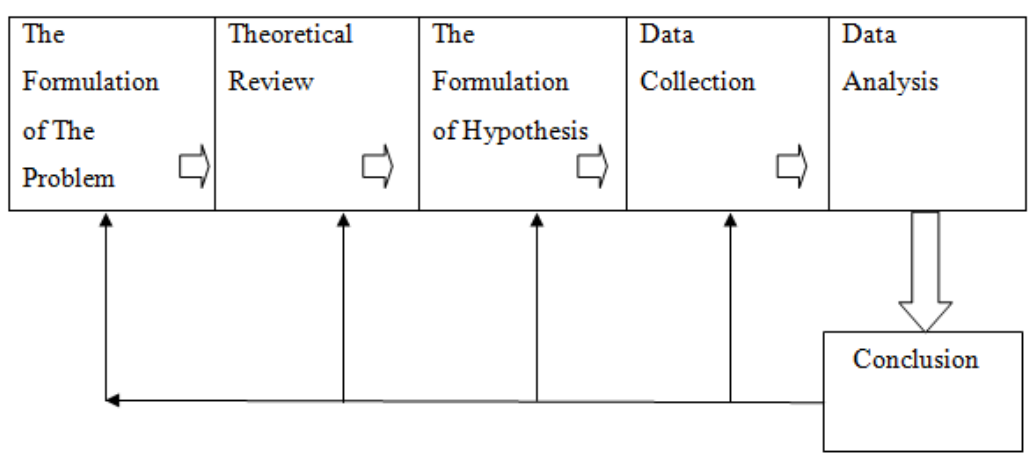

Figure 2

The participants of this research study were Indraprasta PGRI Jakarta University students who were on the fifth semester that took Grammar
Subject. The students were taken out of two classes chosen randomly. One class was a control class and another class was experiment class.

The instrument is a multiple choice of grammar that will be given 
to the control and experimental classes. "Research instrument is a

kind of tool which is used by the researcher to collect or to get the data" (Arikunto, 2006:149).

The data collection technique in this study uses Participation Observation this kind of data collection involves the researcher herself to observe the participant.

There are several techniques that are applied on this research study as follows:

1. Homogeneity Test

2. Normality Test

3. T-Test

$$
\mathrm{t}=\frac{\left|M_{x}-M_{y}\right|}{\sqrt{\left(\frac{\sum_{X} 2+\sum_{y}{ }^{2}}{N_{x}+N_{y}-2}\right)\left(\frac{1}{N_{x}}+\frac{1}{N_{y}}\right)}}
$$

Figure 3

Where;

$\mathrm{t}: \mathrm{t}$-value,

$M_{x}$ : the average deviation of the experimental group,

$\mathrm{M}_{\mathrm{y}}$ : the average deviation of the control group,

$\mathrm{N}_{\mathrm{x}}$ : number of student in the control group,

$\mathrm{N}_{\mathrm{y}}$ : number of student in the experimental group,

$\mathrm{x}$ : deviation of the control group, and

$y:$ deviation of the experimental group.

\section{RESULTS AND DISCUSSION}

Description of Data

This present research purposes to figure out the using of cooperating language learning

1. Homogeneity Test on teaching grammar particularly in higher education level. The data were taken from grammar test, and the result is described as follows:

Test of Homogeneity of Variances

Non_Cooperative_Learning

\begin{tabular}{|c|c|c|}
\hline $\begin{array}{l}\text { Levene } \\
\text { Statistic }\end{array}$ & df1 & df2 \\
\hline 2.313 & 6 & 14 \\
\hline
\end{tabular}

\section{ANOVA}

\begin{tabular}{cccc}
\hline Non_Cooperative_Learning & & & \\
Sum & of & & \\
Squares & Df & Mean Square F & Sig.
\end{tabular}




$\begin{array}{lll}\text { Between } & 993.440 & 10 \\ \text { Groups } & & \\ \text { Within Groups } & 7848.800 & 14 \\ \text { Total } & 8842.240 & 24\end{array}$

On homogeneity test table shows the variances that homogeny or not within the proposed hypothesis as follows:

Ha: English grammar achievement scores of the students taught through cooperative language learning and non-cooperative learning Not Homogeny

Ho: English grammar achievement scores of the students taught through cooperative language learning and non-cooperative learning Homogeny

Requirements:

If $\alpha=0,05$ bigger or equal within score of Sig. or $[\alpha=0$, $05 \geq$ Sig.], then $\mathrm{Ha}$ is accepted and Ho is rejected meaning Not Homogeny.
$99.344 \quad .177$

.995

560.629

If $\alpha=0,05$ smaller or equal within score of Sig. or $[\alpha=0$, $05 \leq$ Sig.], then Ho is accepted and $\mathrm{Ha}$ is rejected meaning Homogeny.

Based on the result of SPSS 16.0 Sig is 0.92 meaning that $\alpha=0,05$ is smaller or equal within score of Sig. or $[\alpha=0,05 \leq \mathrm{Sig}$. $]$, then $\mathrm{Ho}$ is accepted and $\mathrm{Ha}$ is rejected meaning Homogeny. In other words, the data taken English grammar achievement scores of the students taught through cooperative language learning and non-cooperative learning is Homogeny.

\section{Normality Test}

The result of normality test is shown on the following table:

\section{Tests of Normality}

\begin{tabular}{|c|c|c|c|c|c|c|c|}
\hline & & Kolmo & rov- & $\mathrm{OOV}^{\mathrm{a}}$ & Shapi & Nilk & \\
\hline & & Statisti & & & Statis & & \\
\hline & Group & $\mathrm{c}$ & Df & Sig. & $\mathrm{c}$ & $\mathrm{df}$ & Sig. \\
\hline $\begin{array}{l}\text { Scor } \\
\mathrm{e}\end{array}$ & $\begin{array}{l}\text { Non_Cooperative_L } \\
\text { earning }\end{array}$ & .102 & 25 & $.200^{*}$ & .961 & 25 & .430 \\
\hline & $\begin{array}{l}\text { Cooperative_Learni } \\
\text { ng }\end{array}$ & .116 & 25 & $.200^{*}$ & .951 & 25 & .264 \\
\hline
\end{tabular}

a. Lilliefors Significance Correction

*. This is a lower bound of the true significance.

Based on the output of Normality Test, It can be seen that the significant score for Non Cooperative Learning group is 0,430 , while for Cooperative Learning group is 0,264 ; it means that the significant scores of both Non Cooperative Learning and Cooperative Learning are bigger than or > 0, 05; in other words; it can be concluded that the data are distributed normal.

\section{T-Test}

The result of the T-Test by taking the data through the grammar test 
towards the experiment group and control group as follows:

\begin{tabular}{|c|c|c|c|c|c|c|}
\hline \multicolumn{7}{|c|}{ Group Statistics } \\
\hline \multirow{3}{*}{ Score } & Group & $\mathrm{N}$ & Mean & $\begin{array}{l}\text { Std. } \\
\text { Deviation }\end{array}$ & $\begin{array}{l}\text { Std. } \\
\text { Mean }\end{array}$ & Error \\
\hline & $\begin{array}{l}\text { Non_Cooperative_Lear } \\
\text { ning }\end{array}$ & 25 & 63.52 & 19.194 & 3.839 & \\
\hline & Cooperative_Learning & 25 & 79.20 & 12.111 & 2.422 & \\
\hline
\end{tabular}

The differences on average (cooperative learning) is 79,20; (Mean) the control group (non- analyzed case as amount is 25; cooperative learning) is 63,$52 ; \quad$ Standard Deviation is $12,111$. analyzed case as amount is 25; Standard Deviation is 19.194 ,and average (Mean) the experiment group

\begin{tabular}{|c|c|c|c|c|c|c|c|c|c|c|}
\hline \multicolumn{11}{|c|}{ Independent Samples Test } \\
\hline & & \multicolumn{2}{|c|}{$\begin{array}{l}\text { Levene's Test for Equality of } \\
\text { Variances }\end{array}$} & \multicolumn{7}{|c|}{ t-test for Equality of Means } \\
\hline & & \multirow[b]{2}{*}{$F$} & \multirow[b]{2}{*}{ Siq. } & \multirow[b]{2}{*}{$\mathrm{t}$} & \multirow[b]{2}{*}{$d f$} & \multirow[b]{2}{*}{ Sig. (2-tailed) } & \multirow[b]{2}{*}{$\begin{array}{l}\text { Mean } \\
\text { Difference }\end{array}$} & \multirow[b]{2}{*}{$\begin{array}{c}\text { Std. Error } \\
\text { Difference }\end{array}$} & \multicolumn{2}{|c|}{$\begin{array}{l}95 \% \text { Confidence Interval of the } \\
\text { Difference }\end{array}$} \\
\hline & & & & & & & & & Lower & Unper \\
\hline Score & $\begin{array}{l}\text { Equal variances } \\
\text { assumed }\end{array}$ & 6.262 & .016 & -3.454 & 48 & .001 & -15.680 & 4.539 & -24.807 & -6.553 \\
\hline & $\begin{array}{l}\text { Equal variances not } \\
\text { assumed }\end{array}$ & & & -3.454 & 40.494 & .001 & -15.680 & 4.539 & -24.850 & -6.510 \\
\hline
\end{tabular}

The result of data analysis T-Test table above is as follows:

The Proposed Hypothesis Statement:

Ha: There is a significant difference in English grammar achievement scores of the students taught through cooperative language learning

Ho: There is not a significant difference in English grammar achievement scores of the students taught through cooperative language learning

\section{Requirements:}

If $\alpha=0,05$ smaller or equal within score of Sig. or $[\alpha=0$,
$05 \leq$ Sig.], then Ho is accepted and $\mathrm{Ha}$ is rejected.

If $\alpha=0,05$ bigger or equal within score of Sig. or $[\alpha=0,05 \geq$ Sig.], then $\mathrm{Ha}$ is accepted and $\mathrm{Ho}$ is rejected.

Based on the table displayed above the Sig (2-tailed) is 0,001 $<0,05$ means Ho is rejected and $\mathrm{Ha}$ is accepted. In conclusion, there is a significant difference in English grammar achievement scores of the students taught through cooperative language learning.

\section{Interpretation of Data}

\begin{tabular}{lll}
\hline Question & $\begin{array}{l}\text { Experiment } \\
\text { Group }\end{array}$ & Contro \\
& $(\%)$ & $\begin{array}{l}\text { Group } \\
(\%)\end{array}$ \\
\hline $1 \ldots . . . . . .$. any of his movies? & & 72
\end{tabular}




$\begin{array}{lll}\begin{array}{l}\text { a) Have you ever seen } \\ \text { you ever seen }\end{array} & \text { b) Have you ever saw } & \text { c) Did }\end{array}$
2. She doesn't work Mary.
a) the hardest
b) as hard than
c) as hard as

3. Los Angeles is ..city I have ever been to.

96
a) the beautifuler
b) the most beautiful
c) the beautifullest 4. We're thinking of a new office.

68 28
a) opening
b) to open
c) open

5. What are you going to do this weekend? I don't know .I
a) might to go away
b) might go away
c)

may to go away

6. Sunday is Holiday. We work.

92

80
a) don't have to
b) must not
c)

don't must to

7. What will you do if you the exam?
a) don't pass
b) will pass
c) won't pass

8. If we had a yard, I

84

a) will buy

b)would buy

c) bought

9. He went to the supermarket some milk.
a) getting
b) to get
c) get

10. You . coffee late at night.

a) shouldn't to drink

b) shouldn't drink

c) don't should drink

11. I've known my best friend
a) since 4 years
b) for 4 years
c) for 2004

12. How long your car.

a) do you have

b) have you

c) have you had

13. He's divorced now, but he
a) was married
b) is married
c) has been married

14. He. have a lot of friends at school. He wasn't very popular.
a) didn't use to
b) don't used to
c)

didn't used to .in that hotel, it will be very expensive.
a) popularer
b) the most popular
c) more popular

17. John .The dishes.
a) has already done
b) have already done already does
c) has 
18. I don't enjoy ............. to the movies by myself.

56

60
a) to go
b) going
c) go

19. The radio .By Marconi.

80

60

a) invented

b) is invented

c)

was invented

20. If I had a car, I.

..to work.

96

64

a) would drive

b) will drive

c)

drive

21. She's been afraid of flying

40

36

a) for many years

b) since many years

c) for 1998

22. I ................Ana for ages.

88

44
a) knew
b) have know
c) have known

23. You smoke in gas station.

96

84
a) don't have to
b) don't must to
c)

must not to

24. Jack .sad, if he doesn't see you tomorrow.

a) is

b) will be

c) was

25. She with his mother, but now she lives with his father.
a) used live
b) use lived
c) used to
live

Average

Based on the table analysis of answering all the questions above, the result shows difference average between experiment group and control group that one is 79 point in experiment group and 64 in control group. It is clear that in experiment group is higher than control group.

Comparing to experiment group and control group firstly is starting from number (1) within the question"... any of his movies?" that the answer is supposed to be "a) Have you ever seen" in experiment group all the participant answering in correct answer, while in control answer in some variation answer such as b) Have you ever saw or c) Did you ever seen these can be seen on different point score that one is 100 or in excellent category in experiment group and 72 or in good category in control group. However, the experiment group shows the point is higher than the control group.

On number (2) question in experiment group the point shows 96 means in excellent level oppositely in control group 60 means average level. The question is "She doesn't work ...Mary." and the answer should be "c) as hard as", somehow less of experiment group answer incorrect way, yet in control group many participant answer in false answer that they choose to answer a) the hardest or b) as hard than. Hence, the experiment group point is higher than the control group.

Next, the number (3) within the question" Los Angeles is ...city I have ever been to." That the answer is obviously "b) the most beautiful" because the question is about the superlative, however in experiment group, only one participant who 
answers the question incorrect answer, in the opposite group or in control group there are four participants who answer incorrect answer within the number 96 for experiment group includes in excellent level, while 84fro control group includes in good level. Therefore, the experiment group is higher than the control group.

On number (4) within the question is "We're thinking of .... new office." That the correct answer is "a) opening" because preposition that available on the statement must be followed by gerund, in experiment group shows the point that is 68 point (average level) in other words this result shows that still much learning more about the using of gerund, while in control group 28 point (poor level), otherwise it means the participant in control group should learn much about the using of gerund whether intensively or extensively. So, the experiment group is higher than the control group.

Afterward, on the question number (5) shows in experiment group the point is 48 or in weak level and in control group the point is 44 or similar with experiment group that is in weak level. The question is "What are you going to do this weekend? I don't know .I ..." and the appropriate answer is "b) might go away" because the using of might is followed by simple verb not by infinitive. Therefore, the results shows both experiment group and control group are in weak level in doing this question, and it means needing more learning about this case. Even though both groups are in weak level, the experiment group is still higher four points than the control group.

On number (6) the table shows the point of experiment group is 92 means in excellent category, on the other hand, in control group the point is 80 means in good category. The question appears "Sunday is Holiday. We...work." The answer is supposed to be "a) don't have to" because it's about the suggestion. However, the experiment group is higher than the control group.

Next, in number (7) the experiment group point is 72 or in good category, while the control group is 64 means in average category. The question is "What will you do if you ...the exam?" The answer is supposed to be "a) don't pass" because the question type is kind of conditional sentence which the "result clause" uses simple future and the" if clause" is supposed to be in simple present. In assumption, the experiment group on 72 point is higher than the control group in 64 point.

On number (8) the table presents the point of the experiment group is 84 and the point of the control group is 72 . The question is "If we had a yard, I ... a dog." The answer is "b) would buy" because it is about conditional sentence within the "if clause" uses simple past then should be followed with the "result clause" using would and simple verb form. Both groups are in good level. However, the experiment group is higher than the control group.

On number (9) the point of the experiment group is 88 (in good category) and the control group is 92 (in excellent category). The question is "He went to the supermarket ... some milk." The answer is "b) to get" because the main verb "went" is commonly followed by infinitive. To sum up, the experiment point is lower than the control group even the difference point is only 4 points. 
Afterward, on number (10) the experiment group point is 84 (good level) and the control group is 72 (good level). The question is "You ... coffee late at night." The answer is "b) shouldn't drink" it is obviously clear that the modal the pattern of negative should is "should + not + simple verb form". Even though both groups are in good level, the experiment group is higher than the control group.

On number (11) the table shows the point of the experiment group is 56 means in average level and the control group is 32 means in weak level. The question is "I've known my best friend ...." The answer is supposed to be "b) for 4 years" because the using of "for" is followed by stated period of time. However, the experiment group is higher than the control group. Even though the point of experiment group is higher, yet the point is in average level and the control group in weak level, so that both of groups should learn more the using of "for" and "since" in present perfect tense.

On number (12) the experiment point is 72(good level) and the control group is 80 (good level). The question is "How long ........... your car." The answer is "c) have you had" because the pattern of present perfect question is "have + subject + past participle verb". Even though both groups are in good level, the experiment group point is lower than the control group.

Next, on number (13) the table shows that the point of the experiment group is 72 (good level), while the control group is 68 (average level). The question is "He's divorced now, but he ...for 20 years." The answer is "c) has been married" because the first clause is stated in simple present and it means the effect of the next clause that one is in present perfect. To sum up, the experiment group point is higher than the control group point.

On number (14) the experiment point is 52 (average level) and the control group is 56 (average level). The question is "He... have a lot of friends at school. He wasn't very popular." The answer is "a) didn't use to" because the negative pattern of "used to" is "didn't use to". However, both groups are in not really good level and the experiment group is lower than the experiment level. In other words, both groups should learn more of using "used to".

Afterward, on number (15) the point for the experiment group is 84 (good level) and the point for the control group is 40 (weak level). The question is "If he ...in that hotel, it will be very expensive." The answer is "c) stays" because the case is conditional sentence and the using simple future in the "result clause" is followed by simple present in the "if clause". However, the experiment point is higher than the control group that needs more learning on conditional sentence.

Next, on number (16) the table analysis presents the experiment group point is 84 (good level) and the control group 64 (average level). The question is "Basketball is ...than soccer in the US." The answer is "c) more popular" it is obviously clear that the question case is followed by the signal of comparative degree because there is indicator word of "than". However, the experiment group point is higher than the control group.

On number (17) the experiment group point is 84 (good category), while the control group is 76 (good 
category). The question is "John ...The dishes." The answer is "a) has already done" it is obviously clear that the answer must be present perfect requirements. Even though both groups are in good level, the experiment group point is higher than the control group point.

On number (18) the experiment group is 56 (average level) and the control group is 60 (average level). The question is "I don't enjoy ... to the movies by myself." The answer is "going" because the verb "enjoy" is commonly followed by gerund. However, the result both of groups are in average level meaning more doing exercises about gerund. Hence, the point of experiment group is lower than the control group.

Next, on number (19) the experiment group point is 80 (good level) and the control group point is 60 (average level). The question is "The radio ...By Marconi." The answer is "c) was invented" because the case is simple past action so that the appropriate answer is in simple past tense in passive pattern. It can be seen that the experiment group is higher than the control group.

On Number (20) the table analysis presents the point of the experiment group is 96 (excellent category) and the control group 64 (average category). The question is "If I had a car, I...to work." The answer is "a) would drive" the question case is about conditional sentence in the "if clause" uses simple past, so in the "result clause" uses "would + simple verb form". However, the experiment group is higher than the control group.

On number (21) the table analysis shows that the experiment group point is 40 (weak category) and the control group point is 36 (weak category). The question is "She's been afraid of flying ..." The answer is "b) since many years" because the using of "since" in present perfect tense is used when no exact stated period only "many years". However, both groups are in weak category and the experiment group higher 4 points than the control group, yet still both of groups need more learning on using "since" in present perfect.

On Number (22) the experiment group is 88 (good level) and the control group 44 (weak level). The question is "I ....Ana for ages." The answer is "c) have known" it is obviously that the answer should agree within the tense that one is present perfect tense. However, the difference between the experiment group and the control group is very far higher on the experiment group than the control group.

On number (23) the table analysis presents that the point of the experiment group is 96 (excellent category), while the control group is 84 (good category). The question is "You ...smoke in gas station." The answer is "c) must not to" because the statement is about tendency of suggestion. Here, the experiment group point is higher than control group point.

On number (24) the experiment group point is 92 (excellent level) and the control group point is 72 (good level). The question is "Jack ...sad, if he doesn't see you tomorrow." The answer is "b) will be" because the context is in conditional sentence within the "result clause" uses simple present then the "if clause" must uses simple future. Therefore, the experiment group is higher than the control group. 
Last number (25) the table analysis presents the experiment group point is 100 (excellent level) and the control group point is 84 (good level). The question is "She ...with his mother, but now she lives with his father." The answer is "c) used to live" it is very clear that the pattern of the action habits that happened in the past, yet do not happen in the present anymore uses "used to+ simple verb form".

Summing the average on all the question numbers can be seen from the result of the experiment group point that one is 79 meaning in good category, while in the control group average point is 64 meaning on average category.

\section{CONCLUSION}

After the analyzed data calculated there are several results that can be as conclusion those are:

1. The differences on average (Mean) the control group (noncooperative learning) is 63,52 ; analyzed case as amount is 25; Standard Deviation is 19.194 , and average (Mean) the experiment group (cooperative learning) is 79,20 ; analyzed case as amount is 25; Standard Deviation is 12,111 .

2. The T- Test shows that the Sig (2tailed) is $0,001<0,05$ means Ho is rejected and $\mathrm{Ha}$ is accepted. In conclusion, there is a significant difference in English grammar achievement scores of the students taught through cooperative language learning.

The similar topic or field research may be proposed for other methods on grammar teaching. The other methods may be applied such as on the using of Task-Based Language Teaching Method, Community
Language Teaching Method, Direct Method, or Eclectic Method etc.

\section{REFERENCES}

Arikunto, S. (2006). Prosedur Penelitian. Jakarta: PT Asdi Mahasatya.

Cohen, E. G., Brody, C. M., \& Shevin, M. S. (2004). Teaching Cooperative Learning the Challenge for Teacher Education. Albany: State University of New York Press.

Harmer, J. (2007). The Practice of English Language Teaching Fourth Edition. China: Pearson Education

Jolliffe, W. (2007). Cooperative Learning in the Classroom Putting it into Practice. London: Paul Chapman Publishing.

Kagan, Dr. S., \& Kagan, M. (2009). Kagan Cooperative Learning. San Clamente: Kagan Publishing.

Khan, A., \& Akhtar, M. (2017). Investigating the effectiveness of cooperative learning method on teaching of English grammar. Bulletin of Education and Research. April 2017, Vol. 39, No. 1 pp. 1-16.

Patel, Dr. M.F., \& Jain. (2008). English Language Teaching (Methods, Tols \& Tecniques). Jaipur: Sunrise Publishers \& Distributors.

Richards, J. C., \& Rodgers, T. S. (2001). Approaches and Methods in Language Teaching second Edition. Cambridge: Cambridge University Press.

Scrivener, J. (2011). Learning Teaching the Essential Guide To English Language Teaching Third Edition. Oxford: Macmillan Publishers. 
Seely, J. (2007). Grammar for Teachers Unlock Your Knowledge of English. Triverton UK: Oxpecker.

Sugiyono. (2016). Metode Penelitian Pendidikan Pendekatan Kuantitatif, Kualitatif, dan $R \& D$. Bandung: Alfabeta CV

Thornbury, S. (2002). How To Teach Grammar. Malaysia: Bluestone Press.

Trimastuti, W. (2016). The effectiveness of cooperative language learning in teaching vocabulary. IJET, 5(2).
Ur, P. (2006). Grammar Practice Activities: a Practical Guide for Teachers. Cambridge: Cambridge University Press

Woods, G. (2010). English Grammar for Dummies 2nd Edition. Hoboken Canada: Wiley Publishing. Inc.

Zarifi, A., \& Taghavi, A. (2016). The impact of cooperative learning on grammar learning among Iranian intermediate EFL learners. ISSN 17992591Theory and Practice in Language Studies, Vol. 6, No. 7, pp. 142-143 